BENTHM OPEN
CrossMark
Content list available at: www.benthamopen.com/TOMICROJ/

RESEARCH ARTICLE

\title{
The Frequency of Antibiotic Resistance and ESBLs Among Clinically Acinetobacter baumannii Strains Isolated from Patients in a Major Hospital in Tehran, Iran
}

\author{
Reza Ranjbar, ${ }^{1, *}$, Sajjad S. Tolon ${ }^{1}$, Shahin Zayeri ${ }^{1}$ and Mehrdad Sami ${ }^{2}$ \\ ${ }^{I}$ Molecular Biology Research Center, Systems Biology and Poisonings Institute, Baqiyatallah University of Medical \\ Sciences, Tehran, Iran \\ ${ }^{2}$ Department of Clinical Sciences, School of Veterinary Medicine, Ferdowsi University of Mashhad, Mashhad, Iran
}

Received: March 31, 2018

Revised: July 10, 2018

Accepted: July 14, 2018

\begin{abstract}
:
Background:

Bacterial resistance to antibiotics limits treatment options, increases morbidity and mortality, and raises the risk of antibioticassociated adverse events. Antibacterial resistance emerges rapidly following an increase in the consumption of antibiotics against infectious diseases. The spread of ESBL producing strains has a limiting factor based on antibiotic function for the treatment of infections particularly caused by Acinetobacter baumannii (A. baumannii).
\end{abstract}

\section{Objective:}

This study was conducted to evaluate the prevalence of antimicrobial resistance and distribution of $b l a_{T E M}, b l a_{C T X}$, and $b l a_{S H V}$ genes among $A$. baumannii strains isolated from clinical samples at a major hospital in Teheran, Iran.

\section{Methods:}

A. baumannii strains were isolated and identified using standard microbiological methods. The disc diffusion and combined discs methods were used for testing antimicrobial susceptibility and to identify the strains producing Extended-Spectrum Beta-Lactamases (ESBL), respectively. DNA extraction was done by boiling method. Finally, the frequency of resistant genes including $b l a_{T E M}, b l a_{C T X}$, and bla $_{S H V}$ in ESBL producing isolates was studied by PCR.

Results:

Gender distribution in this study was 53 (53\%) samples for men and 47 (47\%) for women. Totally, one hundred A. baumannii strains were isolated. More than $93 \%$ of the isolates were multi drug resistant. The highest to lowest antibiotic resistance was observed against amoxicillin/clavulanic acid (98\%), ceftriaxone (96\%), cefotaxime (94\%), and ceftazidime (93\%), respectively. The frequency of positive phenotypic test of ESBL was $19 \%$ and $16 \%$ for CAZ-C and CTX-C, respectively. The frequency of bla $a_{T E M}$, bla $_{C T X}$, and bla $a_{S H}$ genes was $52.1,43.4$, and 21.7 , respectively.

\section{Conclusion:}

A. baumannii isolates exhibited an extremely worrying level of antibiotic resistance, and a high percentage of the isolates showed MDR in this study. This is a serious warning because ESBLs are a major threat to the effectiveness of antibiotics that are currently available for medical uses. The frequency of genes encoded ESBL isolates of A. baumannii may be due to overuse and misuse of antibiotics.

\footnotetext{
* Address correspondence to this author at the Molecular Biology Research Center, Systems Biology and Poisonings Institute, Baqiyatallah University of Medical Sciences, Tehran, Iran; Tel: 00989123048157; E-mail: ranjbarre@gmail.com
} 
Keywords: Antibiotic, Bacterial resistance, A. baumannii, ESBL, PCR, Clinical samples.

\section{INTRODUCTION}

Bacterial resistance to antibiotics limits treatment options increases mortality and the risk of side effects of antibiotics. Resistance to excessive antibiotic use is increasing rapidly [1]. Extended-spectrum beta-lactamases (ESBL) is responsible for creating resistant strains of bacteria against antibiotics [2 - 4]. Expansion of ESBL producing strains restricted the antimicrobial agents to treat patients effectively and raised concerns for control of infections caused by $A$. baumannii. The misuse of antimicrobial drugs in hospitals can lead to the development of antibiotic-resistant bacteria such as $A$. baumannii. Acinetobacter's hospital strains are usually resistant to several drugs at the same time. $A$. baumannii is more common than other Acinetobacter strains and is the most common cause of bacterial infection. This opportunistic bacteria can survive on a variety of surfaces, including patient skin and medical equipment. Therefore, prolonged hospitalization in the intensive care unit, severe illnesses, immunodeficiency conditions, burn injuries, longterm use of antimicrobial agents, and catheter use are some of the most important risk factors for Acinetobacter infection [5]. A. baumannii is an important opportunistic pathogen responsible for a variety of nosocomial infections; including ventilator-associated pneumonia, bacteremia, surgical site infections, secondary infections of burn patients, secondary meningitis, and urinary tract infections in the Middle East region [6, 7] and other parts of the world $[8,9]$. Hydrolysis of the $\beta$-lactam ring structure by ESBL causes an abnormal antibiotic function. ESBL enzymes are able to target a wide range of antibiotics, such as penicillins and their complexes, monobactams, and new generation cephalosporins [10]. There are hundred types of $\beta$-lactamase enzymes, each of the ESBL bacteria may have genes for one or more of these enzymes. Similar bla genes, similar to the same structure within these gene families, are grouped according to phylogenetic and are often detected and diagnosed by PCR [11]. Transmission of resistance genes between bacteria is easy to do since these genes are encoded on mobile vectors (plasmids and transposons) $[12,13] . \beta-$ lactamases are inactivating enzymes that are present in all types of bacteria. The efficacy of beta-lactam antibiotics in eradicating infection in different places in the body can be reduced by the beta-lactamase producing organisms [14]. By using DNA-based technologies, a new era in the diagnostic and molecular epidemiology of an antibiotic-resistant bacterium opens. The use of PCR-based techniques has revolutionized the rapid diagnosis of determinants of resistance, such as ESBLs $[15,16]$.

We have previously investigated ESBLs genes in some high resistant bacterial species particularly those were isolated from clinical cases [17 - 22].

In this study, we aimed to determine the prevalence of antimicrobial resistance and distribution of $b l a_{T E M}, b l a_{C T X}$, and $b l a_{S H V}$ genes among $A$. baumannii strains isolated from clinical samples at a major hospital in Teheran, Iran.

\section{MATERIALS AND METHODS}

In a cross-sectional descriptive study, from January until the end of June 2017, clinical samples (endotracheal tubes, blood, sputum, urine, catheters, wounds, and various fluids) were recovered from patients admitted to a major Hospital in Tehran.

\subsection{Bacterial Strains Identification}

The samples were transported to the laboratory then were cultured on blood and MacConkey agar for 24 hours at $37^{\circ} \mathrm{C}$ was done. To identify the isolates of $A$. baumannii, the preliminary conventional phenotypic tests including growth on MacConkey agar, sugar fermentation, motility, catalase and oxidase tests, and other standard recommended tests [23, 24]. For definitive identification of these isolates to the species level, molecular methods were used in the next step.

\subsection{Antibiotics Susceptibility Testing}

According to the instructions of the clinical and laboratory standards institute, antibiotic resistance of the isolates was determined using the disk diffusion antibiotic sensitivity test [25]. Antibiotic discs used in this study were including cefotaxime, ceftazidime, amoxicillin/clavulanic acid and ceftriaxone. A. baumannii suspension was expanded after incubation at $37^{\circ} \mathrm{C}$ on Mueller-Hinton agar culture medium and compared to McFarland standard using carpet culture. Then the discs were placed on them. After incubation for 24 hours, the growth inhibition diameter was measured and compared with reference values. 


\subsection{Detection of ESBL Producing Strains}

The phenotypic detection of the different beta-lactamases was performed on Mueller-Hinton medium using discs containing ceftazidime, ceftazidime/clavulanic acid (CAZ-C), cefotaxime, and cefotaxime/clavulanic acid (CTX-C) as previously described [26].

The DNA was extracted from isolates by the boiling method and frequency of TEM, SHV and CTX using specific primers was evaluated, as shown in Table 1 [26, 27]. PCR test was performed using Master Mix, primer, bacterial DNA, and distilled water to obtain a final volume of $25 \mathrm{~mL}$. Except for annealing temperature, the reaction temperature of the PCR for all three beta-lactamase genes was the same. It contained an initial denaturating for 4 minutes at $94^{\circ} \mathrm{C}$, followed by 35 repetitions for 1 minute at $94^{\circ} \mathrm{C}$, amplification at $72^{\circ} \mathrm{C}$ for 40 seconds, and final amplification at $72^{\circ} \mathrm{C}$ for 5 minutes (Table 1). PCR products were electrophoresed on 1.5\% agarose gel containing ethidium bromide at $80 \mathrm{~V}$ for $1 \mathrm{~h}$.

Table 1. Primers used to amplify the genes of beta-lactamase.

\begin{tabular}{|c|c|c|c|}
\hline Target type of $\beta$-lactamase Genes & Primer Sequence & \begin{tabular}{|l|} 
Size of \\
Product (bp)
\end{tabular} & AT $\left({ }^{\circ} \mathrm{C}\right)$ \\
\hline \multirow[t]{2}{*}{ bla $_{T E M}$} & 5'-ATG AGT ATT CAA CAT TTC CG-3' (F) & 867 & 52.2 \\
\hline & 5'-CTG ACA GTT ACC AAT GCT TA-3' (R) & & \\
\hline \multirow[t]{2}{*}{$b l a_{C T X}$} & $5^{\prime}$-TTT GCG ATG TGC AGT ACC AGT AA- 3' (F) & 560 & 60 \\
\hline & $5^{\prime}$-CTC CGC TGC CGG TTT TAT -3' (R) & & \\
\hline \multirow[t]{2}{*}{$b l a_{S H V}$} & 5'-TTA ACT CCC TGT TAG CCA-3' (F) & 860 & 51.2 \\
\hline & $5^{\prime}$-GAT TTG CTG ATT TCG CCC-3' (R) & & \\
\hline
\end{tabular}

F: Forward; R: Reverse; AT: Annealing temperature.

\section{RESULTS}

Totally, one hundred A. baumannii strains were isolated. Gender distribution in this study was 53 (53\%) samples from men and 47 (47\%) of women. The percentage of antibiotic resistance was: amoxicillin/ clavulanic acid (98\%), ceftriaxone (96\%), cefotaxime (94\%), and ceftazidime (93\%). Of these, 93\% of the clinical samples showed multiple antibiotic resistance. The frequency of positive phenotypic test of ESBL was 19\% and 16\% for CAZ-C and CTX-C, respectively. The frequency of resistance genes was 52.1, 43.4, and $21.7 \mathrm{in}$ A. baumannii isolates based on the detection of ESBLs genes including $b l a_{T E M}, b l a_{C T X}$, and $b l a_{S H V}$, respectively (Fig. 1).
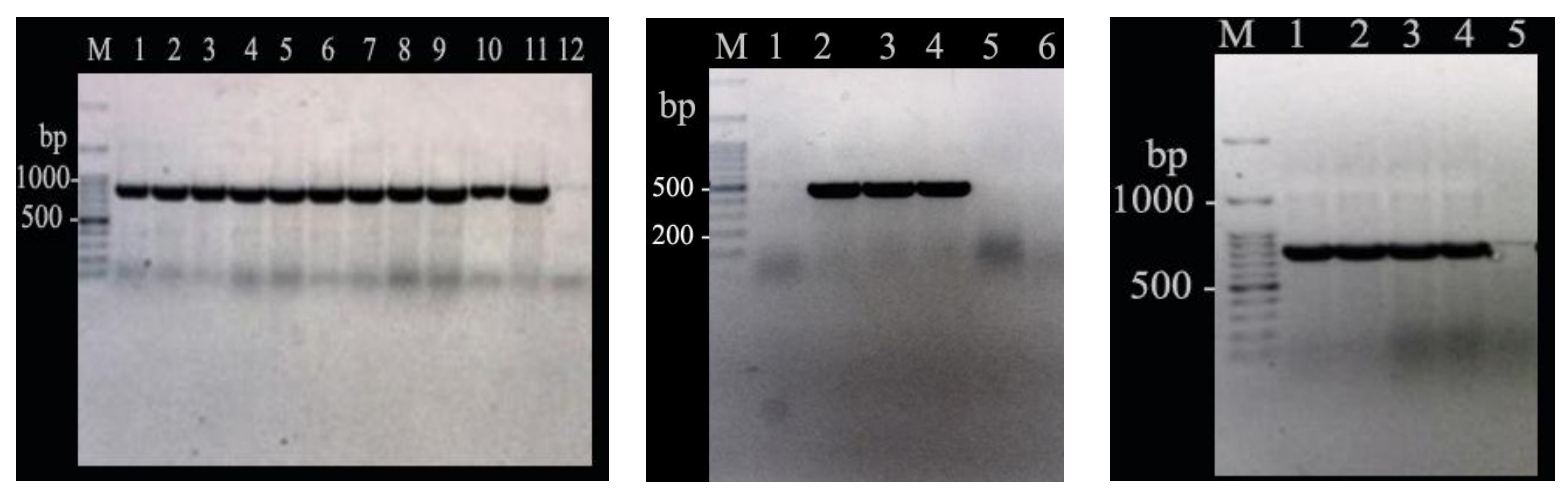

Fig. (1). PCR amplification products of $b l a_{T E M}, b l a_{C T X}$, and $b l a_{S H V}$ (In order from left to right) in some representative Acinetobacter baumannii strains.

\section{DISCUSSION}

In this study, antimicrobial susceptibility testing of $A$. baumannii isolates originally showed highly significant resistance to different types of antibiotics. This resistance can be due to the presence of specific genes of ESBL such as $b l a_{T E M}, b l a_{C T X}$, and $b l a_{S H V}$. Knowing the types and frequency of these genes helps us to make a good decision for the treatment process of patients effectively. High level of multi-drug resistance including Cefotaxime (CTX), Ceftazidime (CAZ), Amoxicillin/clavulanic acid (AMC) and Ceftriaxone (CRO) was observed among the isolates under the study. 
Various factors, including the abuse of antibiotics, the spread of clonal resistant microorganisms, can cause the release of highly resistant pathogens to the environment and clinical setting. Previous researches showed that the prevalence of A. baumannii MDR isolates ranged from $32.7 \%$ to $100 \%$ [28 - 32].

Among the mechanisms that create resistance to drugs, ESBLs play an important role in resistance to conventional antibiotics such as penicillin and cephalosporins. ESBL genes, due to the widespread diffusion of pathogens from the hospital through plasmids and integrons, can further increase drug resistance, including MDR isolates [34, 35].

Jaggi et al. reported that the prevalence of some cephalosporins antibiotics group resistance in the A. baumannii strains of clinical samples against cefepime, ceftazidime, and ciprofloxacin was $90.3 \%, 92.1 \%, 91.6 \%$, respectively [36]. Similar findings have been reported from different countries [37 - 40].

Several studies have reported the frequency of ESBL gene in $A$. baumannii ranging from $25 \%$ to $93.5 \%$ [41 - 44]. In the present study, of the 100 isolates of $A$. baumannii, 39\% of the ESBL producer was consistent with the results of previous studies. Safari et al. reported that $S H V(58 \%)$ and TEM $(20 \%)$ were the highest numbers of ESBL genes in their study [34]. Azhar et al. based on a study that conducted in Iraq, reported that $S H V(25 \%)$ was the most frequently detected ESBL gene [45], while in this study, TEM (52.1) was the most. Khalilzadegan and colleagues identified that $C T X-\mathrm{M}$ and TEM have most ESBL genes [31]. There is some reason to observe the differences in resistance patterns and the prevalence of $A$. baumannii in various investigations including abuse and misuse of antibiotics, differences in the type of antibiotics used, long-term hospitalization, type of samples taken, differences in diagnostic methods used to identify genes, geographical conditions, gender and age of patients, and so on [46, 47].

This study showed high levels of antibiotic resistance in A. baumannii isolates recovered from clinical samples. This is a serious warning because ESBLs are a major threat to the effectiveness of antibiotics that are currently available for medical uses. In this paper, we presented evidence of a great frequency of multi-drug resistant bacteria in clinical samples. Resistance to antimicrobials increasingly undermines the effectiveness of the use of b-lactam antibiotics and other antibacterial drugs that have been effective in the past. To combat antibiotic resistance and develop knowledgebased interventions, a comprehensive understanding of the mechanisms of resistance and the regulation of genes that cause resistance to the material is needed. Molecular methods particularly DNA-based detection techniques help us in the field of diagnostic and molecular epidemiology of antibiotic resistance genes [48 - 50].

\section{CONCLUSION}

A. baumannii isolates exhibited an extremely worrying level of antibiotic resistance, and a high percentage of the isolates showed MDR in this study. This is a serious warning because ESBLs are a major threat to the effectiveness of antibiotics that are currently available for medical uses. The frequency of genes encoded ESBL isolates of $A$. baumannii may be due to overuse and misuse of antibiotics.

\section{ETHICS APPROVAL AND CONSENT TO PARTICIPATE}

Not applicable.

\section{HUMAN AND ANIMAL RIGHTS}

No animals/humans were used for studies that are the basis of this research.

\section{CONSENT FOR PUBLICATION}

Not applicable.

\section{CONFLICT OF INTEREST}

The author declares no conflict of interest, financial or otherwise.

\section{ACKNOWLEDGEMENTS}

We would like to thank from the "Clinical Research Development Center of Baqiyatallah hospital" for their kindly cooperation. This study was supported in part by a grant from "Clinical Research Development Center of Baqiyatallah hospital". 


\section{REFERENCES}

[1] Zhang Y, Marrs CF, Simon C, Xi C. Wastewater treatment contributes to selective increase of antibiotic resistance among Acinetobacter spp. Sci Total Environ 2009; 407(12): 3702-6.

[http://dx.doi.org/10.1016/j.scitotenv.2009.02.013] [PMID: 19321192]

[2] Cantón R, Novais A, Valverde A, et al. Prevalence and spread of extended-spectrum $\beta$-lactamase-producing Enterobacteriaceae in Europe. Clin Microbiol Infect 2008; 14(Suppl. 1): 144-53. [http://dx.doi.org/10.1111/j.1469-0691.2007.01850.x] [PMID: 18154538]

[3] Hawkey PM. Prevalence and clonality of extended-spectrum $\beta$-lactamases in Asia. Clin Microbiol Infect 2008; 14(Suppl. 1): 159-65. [http://dx.doi.org/10.1111/j.1469-0691.2007.01855.x] [PMID: 18154540]

[4] Picozzi SC, Casellato S, Rossini M, et al. Extended-spectrum beta-lactamase-positive Escherichia coli causing complicated upper urinary tract infection: Urologist should act in time. Urol Ann 2014; 6(2): 107-12. [http://dx.doi.org/10.4103/0974-7796.130536] [PMID: 24833818]

[5] Ellis D, Cohen B, Liu J, Larson E. Risk factors for hospital-acquired antimicrobial-resistant infection caused by Acinetobacter baumannii. Antimicrob Resist Infect Control 2015; 4: 40. [http://dx.doi.org/10.1186/s13756-015-0083-2] [PMID: 26457183]

[6] Ranjbar R, Sadeghifard N, Ahmadi A, Izadi M, Zaeimi-Yazdi J, et al. Antimicrobial Susceptibility and AP-PCR Typing of Acinetobacter Spp. Strains. Iran J Public Health 2007; 36(4): 50-6.

[7] Sadeghifarda N, Ranjbarb R, Zaeimic J, Alikhanid MY, Ghafouryana S, Raftarie M, et al. Antimicrobial susceptibility, plasmid profiles, and RAPD-PCR typing of Acinetobacter bacteria. Asian Biomed 2010; 4(6): 901-11.

[http://dx.doi.org/10.2478/abm-2010-0118]

[8] Bergogne-Bérézin E, Towner KJ. Acinetobacter spp. as nosocomial pathogens: Microbiological, clinical, and epidemiological features. Clin Microbiol Rev 1996; 9(2): 148-65 [PMID: 8964033]

[9] Khoshnood S, Eslami G, Hashemi A, Bahramian A, Heidary M, Yousefi N, et al. Distribution of aminoglycoside resistance genes among A baumannii strains isolated from burn patients in Tehran, Iran. 2017; 5.(3)

[10] Livermore DM. beta-Lactamases in laboratory and clinical resistance. Clin Microbiol Rev 1995; 8(4): 557-84. [PMID: 8665470]

[11] Naas T, Zerbib M, Girlich D, Nordmann P. Integration of a transposon Tn1-encoded inhibitor-resistant $\beta$-lactamase gene, bla(TEM-67) from Proteus mirabilis, into the Escherichia coli chromosome. Antimicrob Agents Chemother 2003; 47(1): 19-26. [http://dx.doi.org/10.1128/AAC.47.1.19-26.2003] [PMID: 12499163]

[12] Schink AK, Kadlec K, Schwarz S. Analysis of bla(CTX-M)-carrying plasmids from Escherichia coli isolates collected in the BfT-GermVet study. Appl Environ Microbiol 2011; 77(20): 7142-6. [http://dx.doi.org/10.1128/AEM.00559-11] [PMID: 21685166]

[13] Bailey JK, Pinyon JL, Anantham S, Hall RM. Distribution of the blaTEM gene and blaTEM-containing transposons in commensal Escherichia coli. J Antimicrob Chemother 2011; 66(4): 745-51. [http://dx.doi.org/10.1093/jac/dkq529] [PMID: 21393132]

[14] Ranjbar R, Masoudimanesh M, Dehkordi FS, Jonaidi-Jafari N, Rahimi E. Shiga (Vero)-toxin producing Escherichia coli isolated from the hospital foods; virulence factors, o-serogroups and antimicrobial resistance properties. Antimicrob Resist Infect Control 2017 ; 6(1): 4. [http://dx.doi.org/10.1186/s13756-016-0163-y] [PMID: 28074125]

[15] Behzadi P, Najafi A, Behzadi E, Ranjbar R. Microarray long oligo probe designing for Escherichia coli: An in-silico DNA marker extraction Cent European J Urol 2016; 69(1): 105-11. [PMID: 27123336]

[16] Iversen A, Kühn I, Franklin A, Möllby R. High prevalence of vancomycin-resistant enterococci in Swedish sewage. Appl Environ Microbiol 2002; 68(6): 2838-42 [http://dx.doi.org/10.1128/AEM.68.6.2838-2842.2002] [PMID: 12039740]

[17] Ranjbar R, Giammanco GM, Aleo A, et al. Characterization of the first extended-spectrum beta-lactamase-producing nontyphoidal Salmonella strains isolated in Tehran, Iran. Foodborne Pathog Dis 2010; 7(1): 91-5. [http://dx.doi.org/10.1089/fpd.2009.0382] [PMID: 19785534]

[18] Ranjbar R, Ghazi FM, Farshad S, et al. The occurrence of extended-spectrum $\beta$-lactamase producing Shigella spp. in Tehran, Iran. Iran J Microbiol 2013; 5(2): 108-12. [PMID: 23825726]

[19] Ghafourian S, Bin Sekawi Z, Sadeghifard N, et al. The Prevalence of ESBLs Producing Klebsiella pneumoniae Isolates in Some Major Hospitals, Iran. Open Microbiol J 2011; 5: 91-5 [http://dx.doi.org/10.2174/1874285801105010091] [PMID: 21915229]

[20] Ranjbar R, Sami M. Genetic investigation of Beta-Lactam associated antibiotic resistance among Escherichia coli strains isolated from water sources. Open Microbiol J 2017; 11: 203-10. [http://dx.doi.org/10.2174/1874285801711010203] [PMID: 29151997] 
[21] Abdi S, Ranjbar R, Vala MH, Jonaidi N, Bejestany OB, Bejestany FB. Frequency of bla TEM, bla SHV, bla CTX-M, and qnrA among Escherichia coli isolated from urinary tract infection. Arch Clin Infect Dis 2014; 9(1): e18690. [http://dx.doi.org/10.5812/archcid.18690]

[22] Ranjbar R, Ahmadnezhad B, Jonaidi N. The prevalance of beta lactamase producing Escherichia coli strains isolated from the urine samples in Valiasr Hospital. Biomed Pharmacol J 2014; 7(2): 425-31. [http://dx.doi.org/10.13005/bpj/507]

[23] Forbes BA, Sahm DF, Weissfeld AS. Bailey \& Scott's diagnostic microbiology. $12^{\text {th }}$ ed. St Louis, MO: Mosby 2007.

[24] Golanbar GD, Lam CK, Chu YM, et al. Phenotypic and molecular characterization of Acinetobacter clinical isolates obtained from inmates of California correctional facilities. J Clin Microbiol 2011; 49(6): 2121-31. [http://dx.doi.org/10.1128/JCM.02373-10] [PMID: 21450955]

[25] Turton JF, Kaufmann ME, Glover J, et al. Detection and typing of integrons in epidemic strains of Acinetobacter baumannii found in the United Kingdom. J Clin Microbiol 2005; 43(7): 3074-82. [http://dx.doi.org/10.1128/JCM.43.7.3074-3082.2005] [PMID: 16000417]

[26] Hajjar Soudeiha M, Dahdouh E, Daoud Z, Sarkis DK. Phenotypic and genotypic detection of $\beta$-lactamases in Acinetobacter spp. isolates recovered from Lebanese patients over a 1-year period. J Glob Antimicrob Resist 2018; 12: 107-12. [http://dx.doi.org/10.1016/j.jgar.2017.09.016] [PMID: 28986323]

[27] Aliakbarzade K, Farajnia S, Karimi Nik A, Zarei F, Tanomand A. Prevalence of aminoglycoside resistance genes in Acinetobacter baumannii isolates. Jundishapur J Microbiol 2014; 7(10): e11924. [PMID: 25632323]

[28] Agodi A, Barchitta M, Quattrocchi A, et al. Antibiotic trends of Klebsiella pneumoniae and Acinetobacter baumannii resistance indicators in an intensive care unit of Southern Italy, 2008-2013. Antimicrob Resist Infect Control 2015; 4: 43. [http://dx.doi.org/10.1186/s13756-015-0087-y] [PMID: 26539294]

[29] Mirnejad R, Vafaei S. Antibiotic resistance patterns and the prevalence of ESBLs among strains of A. baumannii isolated from clinical specimens. J Gen Microbes Immunity 2013; 2013: 1-8. [http://dx.doi.org/10.5899/2013/jgmi-00002]

[30] Kheltabadi RF, Moniri R, Shajari GR, Nazem Shirazi MH, Musavi SGA, Ghasemi A, et al. Antimicrobial susceptibility patterns and the distribution of resistance genes among acinetobacter species isolated from patients in shahid Beheshti hospital, Kashan. Feyz J Kashan Univ Med Sci 2009; 12(4)

[31] Khalilzadegan S, Sade M, Godarzi H, et al. Beta-lactamase encoded genes blaTEM and blaCTX among Acinetobacter baumannii species isolated from medical devices of intensive care units in Tehran hospitals. Jundishapur J Microbiol 2016; 9(5): e14990. [http://dx.doi.org/10.5812/jjm.14990] [PMID: 27540447]

[32] Shakibaie MR, Adeli S, Salehi MH. Antibiotic resistance patterns and extended-spectrum $\beta$-lactamase production among Acinetobacter spp. isolated from an intensive care Unit of a hospital in Kerman, Iran. Antimicrob Resist Infect Control 2012; 1(1): 1. [http://dx.doi.org/10.1186/2047-2994-1-1] [PMID: 22958725]

[33] Azizi M, Mortazavi SH, Etemadimajed M, Gheini S, Vaziri S, Alvandi A, et al. Prevalence of extended-spectrum $\beta$-lactamases and antibiotic resistance patterns in A baumannii isolated from clinical samples in kermanshah, Iran. 2017; 10.(12)

[34] Safari M, Mozaffari Nejad AS, Bahador A, Jafari R, Alikhani MY. Prevalence of ESBL and MBL encoding genes in Acinetobacter baumannii strains isolated from patients of intensive care units (ICU). Saudi J Biol Sci 2015; 22(4): 424-9. [http://dx.doi.org/10.1016/j.sjbs.2015.01.004] [PMID: 26150748]

[35] Ribera A, Vila J, Fernández-Cuenca F, et al. Type 1 integrons in epidemiologically unrelated Acinetobacter baumannii isolates collected at Spanish hospitals. Antimicrob Agents Chemother 2004; 48(1): 364-5. [http://dx.doi.org/10.1128/AAC.48.1.364-365.2004] [PMID: 14693570]

[36] Jaggi N, Sissodia P, Sharma L. A baumannii isolates in a tertiary care hospital: Antimicrobial resistance and clinical significance. J Microbiol Infect Dis 2012; 12: 57-63.

[http://dx.doi.org/10.5799/ahinjs.02.2012.02.0043]

[37] Văduva DB, Muntean D, Lonescu G, et al. Antibiotic resistance patterns in Acinetobacter spp. strains isolated from hospital environment. Bacteriol Virusol Parazitol Epidemiol 2008; 53(2): 103-7. [PMID: 19856849]

[38] Mirnejad R, Vafaei S. Antibiotic resistance patterns and the prevalence of ESBLs among strains of A. baumannii isolated from clinical specimens. Journal of Genes, Microbes and Immunity 2013; 1-8.

[39] Reguero MT, Medina OE, Hernández MA, Flórez DV, Valenzuela EM, Mantilla JR. Antibiotic resistance patterns of Acinetobacter calcoaceticus-A. baumannii complex species from Colombian hospitals. Enferm Infecc Microbiol Clin 2013; 31(3): 142-6. [http://dx.doi.org/10.1016/j.eimc.2012.07.013] [PMID: 23021300]

[40] Zhao SY, Jiang DY, Xu PC, et al. An investigation of drug-resistant Acinetobacter baumannii infections in a comprehensive hospital of East China. Ann Clin Microbiol Antimicrob 2015; $14: 7$.

[http://dx.doi.org/10.1186/s12941-015-0066-4] [PMID: 25643932] 
[41] Gupta V, Garg R, Garg S, Chander J, Attri AK. Coexistence of extended spectrum beta-lactamases, AmpC beta-lactamases and metallo-betalactamases in Acinetobacter baumannii from burns patients: A report from a tertiary care centre of India. Ann Burns Fire Disasters 2013; 26(4): 189-92.

[PMID: 24799848]

[42] Shrivastava G, Bajpai T, Bhatambare GS, Patel KB. Sensitivity profile of multidrug resistant Acinetobacter Spp. isolated at ICUs of tertiary care hospital. Int J Health Sys Disaster Manag 2013; 1(4): 200. [http://dx.doi.org/10.4103/2347-9019.130731]

[43] Banerjee M, Chaudhary B, Shukla S. Prevalence of ESBL and MBL in acinetobacter species isolated from clinical samples in tertiary care hospital. Int J Sci Res (Ahmedabad) 2015; 4(6): 1183-6.

[44] Alyamani EJ, Khiyami MA, Booq RY, Alnafjan BM, Altammami MA, Bahwerth FS. Molecular characterization of extended-spectrum betalactamases (ESBLs) produced by clinical isolates of Acinetobacter baumannii in Saudi Arabia. Ann Clin Microbiol Antimicrob 2015 ; 14 : 38. [http://dx.doi.org/10.1186/s12941-015-0098-9] [PMID: 26290183]

[45] Molecular detection of extended-spectrum betalactamases in clinical isolates of A. baumannii. J Biol Agric Healthc 2013; 3(7): 32-9.

[46] Sedighi I, Arabestani MR, Rahimbakhsh A, Karimitabar Z, Alikhani MY. Dissemination of extended-spectrum $\beta$-lactamases and quinolone resistance genes among clinical isolates of uropathogenic Escherichia coli in children. Jundishapur J Microbiol 2015 ; 8(7): e19184. [http://dx.doi.org/10.5812/jjm.19184v2] [PMID: 26421128]

[47] Darvishi M. Virulence factors profile and antimicrobial resistance of $A$. baumannii strains isolated from various infections recovered from immunosuppressive patients In: 2016; 9: pp. (3)1057-62.

[48] Ranjbar R, Karami A, Farshad S, Giammanco GM, Mammina C. Typing methods used in the molecular epidemiology of microbial pathogens: A how-to guide. New Microbiol 2014; 37(1): 1-15. [PMID: 24531166]

[49] Khakabimamaghani S, Najafi A, Ranjbar R, Raam M. GelClust: A software tool for gel electrophoresis images analysis and dendrogram generation. Comput Methods Programs Biomed 2013; 111(2): 512-8. [http://dx.doi.org/10.1016/j.cmpb.2013.04.013] [PMID: 23727299]

[50] Ranjbar R, Naghoni A, Yousefi S, Ahmadi A, Jonaidi N, Panahi Y. The study of genetic relationship among third generation cephalosporinresistant salmonella enterica strains by ERIC-PCR. Open Microbiol J 2013; 7: 142-5.

[http://dx.doi.org/10.2174/1874285801307010142] [PMID: 24358066]

(C) 2018 Ranjbar et al.

This is an open access article distributed under the terms of the Creative Commons Attribution 4.0 International Public License (CC-BY 4.0), a copy of which is available at: (https://creativecommons.org/licenses/by/4.0/legalcode). This license permits unrestricted use, distribution, and reproduction in any medium, provided the original author and source are credited. 